\title{
As jornadas de maio em Goiânia: para além de uma visão sudestecêntrica do junho brasileiro em $2013^{1}$
}

\author{
Francisco Mata Machado Tavares \\ João Henrique Ribeiro Roriz \\ Ian Caetano de Oliveira
}

\section{Introdução}

Os protestos multitudinários intensificaram-se e adquiriram centralidade na cena política brasileira durante o ano de 2013. Um repertório de ações e de formas organizativas menos frequentes ou influentes nos anos antecedentes passou a demandar da ciência social, em especial da ciência política, discursos explicativos e interpretativos. Este artigo insere-se nessa seara e cinge-se aos protestos em favor da mobilidade urbana que tiveram lugar na cidade de Goiânia, capital do estado de Goiás. Inicialmente, a pesquisa aqui relatada procurava responder à seguinte pergunta: qual era a atitude ostentada pelos ativistas estudados em relação à institucionalidade presente nas normas e práticas governamentais e partidárias, próprias ao quadro institucional do constitucionalismo democrático no Brasil contemporâneo?

Percalços de ordem política e científica, contudo, na forma detalhada na seção "Da pesquisa sobre os limites aos limites da pesquisa: percalços políticos e metodológicos do estudo sobre a FLTP em Goiânia", conduziram a pesquisa a uma readequação temática e metodológica. A pergunta norteadora deste artigo, consequentemente, passou a se equacionar assim: o que se pode inferir, a partir do caso da Frente de Luta do Transporte Público (FLTP), sobre as mais comuns generalizações atinentes ao local dos acontecimentos, às demandas expressadas e à relação entre ativismo e repressão nos protestos que tiveram lugar no Brasil em 2013? Tal indagação foi articulada em três eixos, nomeadamente: (i) a contextualização do caso estudado nas tensões de ordem colonial que contrapõem o centro brasileiro, situado no Sudeste, às localidades periféricas, como o Centro-Oeste; (ii) o papel da FLTP na organização dos protestos de 2013 e 2014, com ênfase na relação com outros atores sociais que se somaram às ruas e na coesão ou foco quanto às demandas reivindicadas nas manifestações; e (iii) a relação da FLTP com o Estado, em especial com o respectivo aparato coercitivo.

Antes de detalhar o itinerário que conduzirá este artigo à resposta da pergunta apresentada acima, convém delimitar a sua localização temática e teórica no específico contexto concernente ao campo acadêmico da ciência política. A ideia é voltar-se ao vasto e ainda insuficientemente explorado universo situado às margens dos referenciais

\footnotetext{
${ }^{1}$ Os autores agradecem à equipe do Programa de Pesquisa sobre Ativismo em Perspectiva Comparada (Proluta), da UFG, e a Breno Bringel, do Netsal/Uerj pelas contribuições à pesquisa que informa este artigo.
} 
prevalecentes na produção acadêmica da ciência política brasileira, quais sejam, o neoinstitucionalismo, o deliberacionismo e o neorrepublicanismo ${ }^{2}$. A injunção proposta às teorias políticas mais influentes no Brasil pelos episódios ocorrentes nas ruas desde, ao menos, as lutas antiausteridade na Islândia em 2009 (conhecidas como "Saucepan Revolution") estende-se ao campo crítico ou radical-democrático. Habermas, por exemplo, prócer do deliberacionismo democrático, não foi além de asseverar que "as revoltas juvenis na Espanha e na Grã-Bretanha são um presságio da ameaça à paz social" (Habermas, 2012, p. 5) ${ }^{3}$. A perspectiva teorética aqui assumida procura deslocarse para além dessas visões, de modo a integrar as manifestações de rua como práticas políticas comuns ao universo democrático, antes de problemas a serem elididos ${ }^{4}$.

Direciona-se o foco teórico para perspectivas menos comuns, mas promissoras. 0 escopo é dar conta, metodológica e teoricamente, das idiossincrasias próprias a fenômenos como os protestos dirigidos pela FLTP em Goiânia (objeto deste artigo), o Movimento Passe Livre (MPL) em São Paulo, a Assembleia Popular Horizontal em Belo Horizonte, o movimento Fora Cabral no Rio de Janeiro e o Bloco de Luta pelo Transporte Público em Porto Alegre. São adotadas linhagens menos institucionalizadas e prestigiadas no campo científico da política, as quais tendem a se concentrar sobre objetos correspondentes ao que João Feres Júnior define como "temas-tabu", em função de sua baixa frequência nos artigos e livros vinculados à área (cf. Feres Junior, 2000).

Para adotar um único termo, de origem maquiaveliana, a explicar o objeto social aqui perquirido, propõe-se o tumulto como parte inerente e fundamental da política 5 . Greves, guerrilhas, sequestros de autoridades, boicotes, agrupamentos estrategicamente orientados à derrocada - antes da gestão - de regimes jurídico-políticos e protestos massivos de rua (objeto deste artigo) são, na matriz teorética aqui assumida, quintessencialmente políticos, antes de desvios ou patologias ${ }^{6}$.

\footnotetext{
2 Um levantamento apresentado por Francisco Tavares (2015) indicou que, entre os artigos referentes a pesquisas empíricas de ciência política que apareceram em periódicos classificados no estrato A pela Capes entre os anos de 2007 e 2013, 6,9\% se referiam a espaços participativos institucionais, 10,8\% a deliberação e formação de opinião pública em espaços não formais, 55,9\% à rotina de instituições políticas e apenas $2,8 \%$ a práticas como protestos e conflitos em geral infensos às regras institucionais (algo análogo à ideia de política confrontacional transgressiva).

3 Tradução livre. Na versão consultada, em inglês: "The youth revolts in Spain and Great Britain are a portent of the threat to social peace".

${ }^{4}$ Procura-se, com efeito, entender as manifestações de 2013 no Brasil para além do que Breno Bringel, a propósito das limitações atinentes às leituras mais comuns sobre o tema, definira como "miopia da política", assim explicada como aquela que "restringe a vida política à sua dimensão político-institucional, limitando as possibilidades de compreensão da reinvenção da política e do político a partir das práxis sociais emergentes" (Bringel, 2013, p. 44).

${ }^{5}$ Conforme se lê em uma das mais conhecidas passagens do autor: "Direi que quem condena os tumultos entre os nobres e a plebe parece censurar as coisas que foram a causa primeira da liberdade de Roma" (Maquiavel, 2007, p. 21-22).

${ }^{6}$ A releitura, de matriz derridadiana, proposta por Costas Douzinas para o termo grego Adikia (usualmente entendido como injustiça) é especialmente relevante na compreensão de política assumida neste artigo. A Adikia seria, a um só tempo, a luta incessante entre Techne (o poder humano criativo e violento sobre a ordem preestabelecida) e Dike (a ordem em que o ser humano se encontra no mundo e com a qual se digladia) e o limite entre elas. A forma política da Adikia é, para o autor em questão, "a confrontação da ação humana, variável de época em época, com a 'segunda' natureza dos padrões sociais e hierarquias" (tradução livre) (Douzinas, 2013, p. 78). A resistência e a negação ganham, aqui, o papel principal, antes
} 
Uma vez situado o problema da pesquisa e a sua localização no campo da ciência política, é possível apresentar o itinerário seguido pela presente exposição. Na segunda seção, "Da pesquisa sobre os limites aos limites da pesquisa: percalços políticos e metodológicos do estudo sobre a FLTP em Goiânia", apresentam-se os percalços de ordem política e metodológica que implicaram um desvio sobre a rota previamente planejada, de modo a ser redefinidos a pergunta, o tipo de investigação e as técnicas de pesquisa adotadas. Na terceira seção, "Dias de luta: narrativa e periodização dos protestos em favor do transporte público na cidade de Goiânia entre maio de 2013 e dezembro de 2014", narra-se a trajetória da FLTP no período mencionado no título da seção. Enfim, na quarta seção, "Três 'cisnes negros' identificados no estudo de caso", expõe-se a dinâmica da atuação da FLTP em relação ao respectivo ambiente político e jurídico, sob os prismas da tensão centro-periferia, da coesão na condução dos protestos e da relação com a coerção e a persecução penal do Estado.

\section{Da pesquisa sobre os limites aos limites da pesquisa: percalços políticos e metodológicos do estudo sobre a FLTP em Goiânia}

A pesquisa originariamente planejada pretendia compreender a atitude dos ativistas da Frente de Luta do Transporte Público (FLTP) que conduziram as manifestações de rua em Goiânia (GO), no ano de 2013, perante a institucionalidade estatal. Pleiteava-se o alcance dos seguintes objetivos específicos: (i) mapeamento da gênese, da organização, da pauta de reivindicações, dos vínculos institucionais e partidários, da composição a partir de outros movimentos/grupos, do processo de autonomização política, das formas de comunicação (particularmente quanto às novas tecnologias de informação) e do repertório de ação política da FLTP antes, durante e após as manifestações ocorridas entre maio e setembro de 2013; (ii) identificação da percepção das/dos ativistas da FLTP sobre os canais institucionais de participação pública e as possibilidades de atendimento às suas reivindicações pontuais; e (iii) produção de dados empíricos qualitativos primários sobre o perfil sociocultural das/dos ativistas da FLTP.

Foi implementada, mas posteriormente interrompida em meio ao seu curso operativo, a técnica de pesquisa concernente à realização de entrevistas em profundidade com as/os ativistas. Ademais, seriam realizados grupos focais com integrantes da FLTP, para os quais já havia agendamento, financiamento e logística definidos. Os dados empíricos decorrentes desses levantamentos seriam a principal base a se analisar, para fins de alcance dos objetivos acima sumarizados.

Uma inesperada sucessão de eventos, todavia, ocorrentes quando a pesquisa já se encaminhava para a produção do respectivo relatório, demandou significativa revisão do problema investigado, assim como do curso metodológico seguido. Uma operação policial

das formas organizadas de dominação (Techne) ancoradas em premissas pré-ordenadas (Dike). 
conduzida conjuntamente pelo Serviço de Inteligência e pela Delegacia de Repressão às Ações Criminosas Organizadas (Draco) da Polícia Civil do estado de Goiás surpreendeu, a um só tempo, fontes e pesquisadores envolvidos nos trabalhos científicos que levaram à produção deste artigo. A operação, denominada "2,80", nome associado ao valor majorado das tarifas do serviço público de transporte urbano na cidade de Goiânia, cumpriu, na madrugada do dia 23 de maio de 2014, mandados de prisão preventiva e de busca e apreensão contra militantes da FLTP. Na oportunidade, a autoridade policial concedeu entrevistas aos meios de comunicação local, valendo-se da ampla visibilidade que o assunto angariou em âmbito regional, para anunciar, reiterada e enfaticamente, que novas prisões teriam lugar nos dias subsequentes.

O impacto dessa ação junto aos integrantes da FLTP foi expressivo e produziu desdobramentos sobre esta pesquisa científica. O fato é que as autoridades policiais, sob o pretexto de investigarem ilícitos penais, voltaram-se a procurar panfletos, atas de reuniões, declarações políticas, textos programáticos, artigos acadêmicos e todo tipo de material que permitisse uma compreensão pormenorizada quanto ao funcionamento, à causa motivadora e ao perfil dos aderentes de protestos em favor da mobilidade urbana no município de Goiânia.

A ação coercitiva produziu efeitos diretos sobre a pesquisa que informa este artigo. Isso se deu porque um dos ativistas contra quem foram expedidos os mandados de prisão preventiva e de busca e apreensão é bolsista do projeto no contexto do qual se conduzia a pesquisa. Dentre as tarefas assinaladas ao pesquisador, compreendia-se, precisamente, o armazenamento de informações que foram apreendidas - como arquivos compostos de panfletos, trabalhos gráficos e textos acadêmicos sobre movimentos sociais - e um computador cujo disco rígido guardava material empírico a ser utilizado neste artigo. Em suma, às vésperas da conclusão da pesquisa, as atividades alcançaram o limite de sua inviabilização, em função da apreensão dos dados e da detenção de um bolsista revestido de tarefas fundamentais.

Ademais, tornou-se ética e operacionalmente problemática a manutenção ou divulgação de bases de dados com entrevistas ou documentos atinentes à FLTP e aos respectivos militantes, diante da iminência de novas detenções e da apresentação, pela polícia, de livros acadêmicos ${ }^{7}$ e panfletos como indícios de práticas delituosas. Assim, as entrevistas com aderentes aos protestos de 2013 foram interrompidas e, adicionalmente, optou-se pela não utilização dos materiais já levantados.

Uma guinada quanto ao tipo de pesquisa adotada fez-se, a partir dos fatos acima narrados, imperativa. O estudo planejado como suficientemente objetivo e adepto de técnicas de pesquisas convencionalmente utilizadas no âmbito da ciência política foi reposto por um trabalho associado à pesquisa participante, em sua variante pesquisa-

\footnotetext{
${ }^{7}$ Um exemplo de material apreendido na casa de um pesquisador pela Polícia Civil do estado de Goiás como indício de crime é o livro Cidades rebeldes, publicação da editora Boitempo que reúne contribuições de autores como Slavoj Zizek, David Harvey e Mike Davis. A obra, devidamente "periciada", só seria restituída ao proprietário seis meses após a apreensão.
} 
ação. Notou-se que, diante de um contexto em que o acervo da pesquisa estava parcialmente apreendido por autoridades policiais e um membro da equipe encontrava-se recolhido em um presídio, a única forma de prosseguimento da investigação científica seria a da intervenção sobre a realidade, de modo a restabelecer as próprias condições em que uma produção acadêmica de ordem mais ortodoxa tivesse lugar.

Assim, os autores deste artigo, a partir das prisões e dos mandados de busca e apreensão, passaram a se envolver politicamente com o objeto pesquisado e assumiram vínculos e compromissos com o conjunto de atores relacionados ao ativismo que até então se conformara apenas como objeto de análise. Um dos autores somou-se ao coletivo de advogados que atuaram em favor da libertação dos militantes detidos e se engajou, adicionalmente, em negociações políticas, elaboração de documentos públicos, reuniões com lideranças de movimentos e partidos, dentre outras tarefas congêneres. 0 outro autor também se dedicou à ativa participação em atos públicos, reuniões e assembleias. Por fim, um terceiro autor esteve preso e remanesce como objeto de procedimento investigativo.

A partir da reorientação quanto ao modo de pesquisa acima justificado, o próprio problema norteador da investigação acadêmica demandou uma reformulação. Isso ocorreu porque, como se sabe, a pesquisa-ação se orienta conforme parâmetros de validação e de justificação peculiares, nos termos da seguinte diferenciação: "Pesquisadores convencionais se preocupam com objetividade, distanciamento e controles. Praticantes de pesquisa-ação se preocupam com relevância, mudança social e validade testada na ação pelas partes interessadas que se encontram sob maior risco"8 (Brydon-Miller, Greenwood e Maguire, 2003, p. 25). Ainda além, encampou-se a tese marxiana segundo a qual uma conduta científica crítica deve ser condizente com a máxima de que "nada nos impede de fazer da crítica da política, da participação na política, e, assim, das lutas reais, o ponto de partida da nossa crítica, e de identificarmos a nossa crítica com elas" (Marx, 1843) ${ }^{9}$.

Ao analisarem inquéritos policiais e documentos jurídicos, além de participarem de incontáveis reuniões, assembleias e atos públicos, os pesquisadores tiveram contato com robusto material empírico que, sob o devido filtro analítico e teorético, habilitou a produção de respostas válidas à indagação concernente aos padrões de interação entre a FLTP e o respectivo ambiente jurídico-político, sob os três prismas especificados acima, na seção introdutória.

A pesquisa-ação aqui relatada conformou-se como um estudo de caso centrado sobre a trajetória da FLTP entre maio de 2013 e dezembro de 2014. Adotou-se a corrente epistêmico-metodológica liderada por Bent Flyvbjerg, para quem essa maneira de fazer

\footnotetext{
8 Tradução livre. No original: "conventional researchers worry about objectivity, distance, and controls. Action researchers worry about relevance, social change, and validity tested in action by the most at-risk stakeholders".

9 Tradução livre. Na versão anglófona consultada: "nothing prevents us from making criticism of politics, participation in politics, and therefore real struggles, the starting point of our criticism, and from identifying our criticism with them".
} 
ciência social permite a identificação dos "cisnes negros" que lastreiam as práticas popperianas de falseamento ${ }^{10}$. O autor em questão, notório na epistemologia das ciências sociais por sugerir um fazer científico não apenas epistêmico, mas phronético, consegue constatar, após uma profunda incursão sobre a história das ciências, que a capacidade de generalização das grandes descobertas não decorre necessariamente do número de casos abordados nos estudos. Ao contrário, em Newton, Einstein, Bohr, Freud, Marx e Darwin, dentre incontáveis outros, nota-se, segundo Flyvbjerg (2011), a adoção dos estudos de caso como centrais em seus trabalhos e aptos à produção de generalizações. O estudo de caso é rentável, com efeito, não apenas para a preparação de outras pesquisas ou na condição de pressuposto dos trabalhos comparativos, mas como modo de pesquisa científico-social revestido de valor intrínseco.

A compreensão do caso em questão permitiu, como as seções seguintes justificam, a produção de três achados contraintuitivos, ou "cisnes negros". Primeiramente, refutase a disseminada ideia de que os protestos de 2013 tiveram início em São Paulo (i). Em seguida, afasta-se a tese de que os protestos de 2013 traduziram uma explosão niilista ou anômica, sem foco ou coesão entre manifestantes (ii). Finalmente, propõe-se que a relação entre repressão e protestos de rua não se explica conforme mecanismos universalmente válidos, concluindo-se que, em Goiânia, o aparato policial, afinal, contribuiu para a contenção do exercício da oposição política (iii). Antes de abordar tais questões diretamente, procede-se a uma narrativa histórica dos principais episódios a envolver a FLTP entre maio de 2013 e dezembro de 2014, nos termos da seção seguinte.

\section{Dias de luta: narrativa e periodização dos protestos em favor do transporte público na cidade de Goiânia entre maio de 2013 e dezembro de 2014}

A Frente de Luta pelo Transporte Público é uma organização de movimento social mais precisamente, uma coalizão de campanha - com atuação em Goiânia e região metropolitana. O agrupamento é composto, em sua maioria, por jovens estudantes universitários e secundaristas. Dentre os integrantes da FLTP contam-se militantes sem vínculos organizativos com outras formas associativas, ativistas afiliados a outros movimentos sociais e militantes de partidos ou organizações políticas situados na oposição de esquerda ao governo federal. Ideologicamente, a FLTP se situa à esquerda do espectro político e congrega uma multiplicidade de aderentes, que oscilam das distintas variantes do marxismo às concepções autonomistas e libertárias.

A gênese remota da FLTP fora uma outra coalizão de campanha ${ }^{11}$, denominada

\footnotetext{
${ }^{10}$ Nas palavras do autor: "The case study is ideal for generalizing using the type of test which Karl Popper called 'falsification'. Falsification is one of the most rigorous tests to which a scientific proposition can be subjected: if just one observation does not fit the proposition it is considered not valid generally and must therefore be either revised or rejected (...). The case study is well suited to identifying 'black swans' because of its in-depth approach: what appears to be 'white' often turns out on closer examination to be 'black'" (FLyvbjerg, 2011, p. 76-77).

${ }^{11}$ Os conceitos de "organização de movimento social" e "coalizão de campanha" aqui empregados seguem
} 
Frente Contra o Aumento, que atuara em maio de 2012, orientada a impedir o aumento da tarifa do transporte público urbano. Essa campanha já reunia significativa parcela dos atores e exercia considerável porção do repertório que a FLTP assumiria posteriormente. A iniciativa, todavia, segundo relato de pessoas que a integraram, restou malograda e não deu origem a uma organização coesa ou novas campanhas em função de dois fatores, mutuamente relacionados, quais sejam: i) diminuta adesão de ativistas; e ii) intensa repressão estatal.

A FLTP, por sua vez, consolidou-se como sua sucessora entre os fins de 2012 e o início de 2013. O conjunto de aderentes à FLTP se revelou eclético e deu conta de três tipos de ativistas, sob o critério da experiência pretérita: i) primeiramente, havia um conjunto de militantes e de organizações que esteve na FLTP desde os seus primeiros dias e, ademais, contava com experiência prévia em lutas associadas ao transporte coletivo; ii) em segundo lugar, havia aqueles que aderiram à FLTP desde o seu início, mas não traziam a bagagem de uma atuação em lutas pretéritas; e iii) enfim, houve pessoas e organizações que aderiram, sem vinculação anterior ao tema do transporte público, quando a FLTP já estava constituída.

O ambiente social em que a FLTP atua é uma região metropolitana com população de aproximadamente 2 milhões e 400 mil habitantes. Trata-se da capital com os maiores índices de desigualdade da América Latina (Serodio, 2012), de acordo com o índice de Gini - cujo valor é de 0,65 . A cidade sofre um intenso e não ordenado crescimento nos últimos anos e experimenta elevados índices de criminalidade, posicionando-se como a $28^{a}$ maior taxa mundial de homicídios por 100 mil habitantes (Borges, 2014). Trata-se, ademais, de um município definido por problemas estruturais no serviço de transporte público. O automóvel individual é definido como meio de mobilidade preferencial. A cidade apresenta o mais elevado índice de automóveis por habitantes no Brasil, com um carro para cada 1,6 moradores (Oliveira, 2009). O prefeito da cidade, Paulo Garcia, é filiado ao PT - partido da presidente da República - e governa em uma coalizão integrada pelo PMDB, um dos maiores partidos brasileiros. O governador do estado, Marconi Perillo, é filiado ao PSDB, principal legenda oposicionista ao governo federal.

É nesse contexto que o movimento estudado surge e atua. A sua principal causa é a melhoria na qualidade e a redução nas tarifas do serviço público de transporte coletivo urbano. A principal prática contida no repertório dos/das ativistas reside nos protestos públicos de rua. Uma narrativa dessas ações e dos respectivos desdobramentos revela-se pertinente para a compreensão do objeto desta pesquisa.

Em 8 de maio de $2013^{12}$ organizou-se o primeiro protesto oficialmente chamado

\footnotetext{
o sentido expressado em Tarrow (2009).

12 À exceção do ato de 20 de junho de 2013, não são apresentados números referentes ao contingente de manifestantes aderentes aos protestos. Essa opção decorre do fato de que não há um mínimo acordo entre jornalistas, policiais e ativistas quanto a tais dados. Do mesmo modo, inexiste uma metodologia clara e transparente para o levantamento dessa informação nos protestos de Goiânia. Em geral, atribuiu-se, nos diferentes protestos anteriores ao de 20 de junho, uma presença oscilante entre 200 pessoas (nas mais austeras estimativas apresentadas pela Polícia Militar) e 3.000 manifestantes (segundo as versões mais
} 
pela FLTP, à época ainda conhecida como Frente de Lutas Contra o Aumento. A manifestação parou o trânsito por várias horas, reivindicando a vinda de algum membro da Companhia Metropolitana de Transportes Coletivos (CMTC), órgão regulador do transporte público na região metropolitana de Goiânia, para recebimento de uma carta de reivindicações. A repressão policial foi gradativamente aumentando, com a chegada de destacamentos cada vez mais armados e aumento da pressão para que o protesto liberasse a via. Após intensa negociação, deu-se o comparecimento de uma servidora da CMTC, para quem se franqueou uma breve fala no carro de som utilizado pelo movimento.

Em 16 de maio de 2013 ocorreu um protesto que seguiu em marcha pelo principal corredor viário da capital, a Avenida Anhanguera, para aportar em um importante terminal de ônibus, denominado Praça A. A ideia dos ativistas era discutir com a população os problemas do transporte. Tal empreitada não se realizou, uma vez que, antes da entrada da manifestação, o terminal havia sido esvaziado e fez-se um cordão policial de isolamento. A tensão culminou no primeiro, e consideravelmente grave, embate entre ativistas e policiais. Pessoas se feriram, gás lacrimogêneo foi utilizado, bombas de efeito moral foram lançadas contra os ativistas e, enfim, ocorreram disparos de arma letal. Houve grande repercussão na imprensa. Estava marcada para aquela data a reunião da Câmara Deliberativa do Transporte Coletivo (CDTC), órgão que decidiria sobre o aumento da tarifa. A reunião foi cancelada e remarcada para o dia 21 de maio de 2013.

Na data acima mencionada, realizou-se um protesto às portas do Palácio Pedro Ludovico, sede do governo estadual, local onde ocorreria uma reunião do órgão colegiado $\mathrm{CDTC}^{13}$. A expectativa era de que a reunião fosse aberta, em respeito ao princípio da gestão democrática da cidade, por meio da participação da população, prescrito no artigo $2^{\circ}$, inciso II, da Lei 10.257/2011, conhecida como Estatuto da Cidade. Afinal, após longas negociações, um grupo de três pessoas foi autorizado a entrar no edifício. Todavia, diferentemente do imaginado por quem ficara nas ruas, os três ativistas foram apenas mantidos no prédio governamental, sem nenhum acesso à CDTC. Ainda naquele dia anunciou-se o aumento da tarifa.

Em 28 de maio de 2013 ocorre uma virada na relação entre autoridades policiais e

hiperbólicas transmitidas por ativistas e jornalistas). A observação efetivada pelos autores indica que, em média, as manifestações envolviam aglomerações com extensão de aproximadamente 200 metros de comprimento, compreendendo a largura de uma pista das maiores avenidas da cidade.

${ }^{13} \mathrm{O}$ órgão em questão é composto, exclusivamente, de representantes do aparato burocrático estatal. Não há, pois, qualquer participação deferida à sociedade civil. Confira-se a sua atual conformação: Eduardo Alexandre Zaratz Vieira da Cunha - presidente da CDTC e secretário de estado da região Metropolitana de Goiânia -, Paulo de Siqueira Garcia - prefeito municipal de Goiânia -, Luiz Alberto Maguito Vilela - prefeito municipal de Aparecida de Goiânia -, Misael Pereira de Oliveira - prefeito municipal de Senador Canedo -, Humberto Tannús Júnior - presidente da AGR (Agência Goiana de Regulação, Controle e Fiscalização de Serviços Públicos) -, Ubirajara Alves Abbud - presidente da CMTC (Companhia Metropolitana de Transportes Coletivos) -, Patricia Pereira Veras - secretária municipal de Trânsito, Transporte e Mobilidade de Goiânia -, Nelcivone Soares de Melo - secretário municipal de Desenvolvimento Urbano Sustentável de Goiânia -, Talles Barreto - deputado estadual. 
manifestantes, com um recrudescimento significativo da repressão aos ativistas. Na ocasião, ocorreu um protesto com saída da Praça Universitária, complexo onde se localizam diversas unidades acadêmicas da UFG e da PUC-GO. Os manifestantes marcharam até o Terminal da Praça da Bíblia, um importante elo entre as regiões centrais e a periferia da cidade. O protesto ocorreu no período noturno e, novamente, o terminal de ônibus fora esvaziado e isolado por forças policiais. Uma vez mais, houve confronto. Dessa feita, em escala exponencialmente ampliada. Os militares se utilizaram da cavalaria e do pelotão de choque. Inúmeros ativistas se refugiaram nas dependências da Faculdade de Direito da UFG, no Setor Universitário. Lá, após horas de cerco policial, negociou-se a saída dos manifestantes.

Em 30 de maio de 2013, teve início, em Goiânia, na mesma Praça Universitária, o Congresso da União Nacional dos Estudantes (UNE). Ao desembarcar na cidade, o então presidente da referida entidade, Daniel Iliescu (filiado ao PCdoB, partido integrante da base de apoio ao governo federal), criticou os manifestantes que aderiram ao protesto ocorrido dois dias antes. Ainda no aeroporto, o dirigente concedeu uma entrevista em que combatia publicamente táticas que seguem uma lógica própria à atualidade, como o uso de máscaras ${ }^{14}$. O Congresso presidido por Iliescu recebera, para a sua realização, vultoso financiamento do governo do estado de Goiás, ao qual se subordina a Polícia Militar.

Nesse contexto de manifestações com embates cada vez mais profundos, chegou-se ao mês de junho de 2013, quando se alastraram pelo país inúmeras mobilizações multitudinárias. Teve lugar um quadro de contestação e de mobilização social, concomitante à realização da Copa das Confederações da Fifa no país. Na cidade de São Paulo, uma cartografia da rede social Facebook elaborada por Sérgio Amadeu Silveira e Tiago Pimentel detectou que, até o dia 13 de junho, quando a capital paulista contava três atos públicos referentes ao transporte, esse assunto e a violência policial eram os principais temas em discussão no contexto das interações sobre manifestações (cf. Silveira e Pimentel, 2013). Iniciava-se o momento histórico definido como "Jornadas" ou, mais cautelosamente, "acontecimentos" (cf. Singer, 2013) de junho. Os protestos que, em maio, movimentaram cidades como Natal, Porto Alegre e Goiânia chegavam, um mês depois, às ruas de capitais localizadas nas regiões mais densas demograficamente e industrializadas, como Rio de Janeiro, São Paulo e Belo Horizonte. A insurreição gestada no Brasil periférico alcançava, enfim, o centro econômico brasileiro.

No dia 6 de junho de 2013, em Goiânia, realizou-se novo ato. Os ativistas dirigiram-se à central operacional do órgão responsável por coordenar horários e fluxos dos ônibus urbanos. Novamente, houve tensão entre polícia e manifestantes, que tiveram

\footnotetext{
${ }^{14}$ Do subcomandante Marcos, do Exército Zapatista de Libertação Nacional (EZLN), seguindo-se pelos militantes de Seattle em 1999 na reunião da OMC e de Gênova em 2001, chegando-se a incontáveis momentos posteriores, o uso de máscaras passou a integrar o repertório dos protestos, como meio de evitar retaliações estatais, de cultivar uma nova estética ativista e de proteger os militantes do efeito direto dos gases tóxicos utilizados pelo poder público.
} 
de se refugiar no Instituto Federal, uma instituição pública de ensino superior.

No dia 19 de junho de 2013, data precedente à mais multitudinária das manifestações organizadas em Goiânia, o aumento da passagem de ônibus foi revisto, voltando a tarifa ao seu valor anterior. Era a primeira conquista, em termos de reversão de uma política pública tarifária, obtida pelo movimento.

Em 20 de junho de 2013 aconteceu um dos maiores protestos públicos da cidade de Goiânia, com par apenas em momentos como as Diretas Já (1984) e o Fora Collor (1992). Aproximadamente 50 mil pessoas ganharam o centro da cidade, em um final de tarde que se consubstanciou como um feriado informal, quando comércio, escolas e órgãos públicos suspenderam as respectivas atividades. $O$ ato fora chamado dias antes pela FLTP que, em 19 de junho, realizou uma última e ampla reunião preparatória, com a presença de aproximadamente 90 pessoas. Ali, detalhes como as pautas reivindicatórias e os itinerários a serem adotados foram acertados.

O ato público ganhou uma dimensão não antevista, tornou-se diversificado em suas pautas e não atendeu aos parâmetros deliberados no dia anterior. Policiais militares distribuíram flores aos transeuntes. Cartazes com frases mutuamente contraditórias ${ }^{15}$, massas caminhando em direções diferentes e uma profunda hostilidade contra os ativistas que estiveram nas primeiras marchas deram o tom daquele protesto. Militantes de partidos da oposição de esquerda, até então aceitos sem grandes turbulências em todos os protestos, foram agredidos. O itinerário decidido, que previa o término do ato na Assembleia Legislativa, fora substituído por um apolítico trajeto que se encerrou em um bairro residencial nobre, chamado Setor Bueno, onde não há qualquer repartição governamental, mas inúmeros bares e casas noturnas, destino de grande parte da massa naquela noite. Grupos minoritários mantiveram-se leais às deliberações prévias e seguiram para as imediações da Assembleia Legislativa, onde foram alvo de embate com a tropa de choque e com a cavalaria, culminando em alguns feridos. Nesse dia, ocorreu algo que parece enquadrar-se na ideia de "desbordamento societário", proposta por Breno Bringel (2013) para interpretar a relação de não identidade entre movimentos "madrugadores" - como a FLTP - e "derivados", como os que estavam nas ruas em 20 de junho' ${ }^{16}$.

A partir do ato de 20 de junho, avaliando a situação como inédita, mas também confusa, a FLTP optou por iniciar uma série de trabalhos de discussão interna, que

\footnotetext{
15 Havia, por exemplo, os que pediam a redução da carga tributária do "setor produtivo" e os que clamavam por mais impostos para os empresários. Alguns criticavam a homofobia, enquanto outros ostentavam cartolinas dizendo "Ronaldo, você diz que não se faz copa com hospitais, mas com estádios. Eu te digo: sexo se faz com mulheres, não com travestis".

${ }^{16}$ Confira-se: "Um ponto central aqui é que, ao contrário do previsto pelas teorias dos movimentos sociais, os movimentos derivados aproveitaram-se, no Brasil, dos espaços abertos pelas mobilizações iniciais, sem, contudo, manter laços fortes, enquadramentos sociopolíticos, formas organizativas, referências ideológicas e repertórios de mobilização que os unam ao MPL e/ou a outros iniciadores. Essa aparente desconexão relaciona-se a um fenômeno que gostaria de denominar como desbordamento societário, ou seja, quando na difusão de setores mais mobilizados e organizados a setores menos mobilizados e organizados, os grupos iniciadores acabam absolutamente ultrapassados" (Bringel, 2013).
} 
culminariam em uma ampliação das respectivas pautas. O movimento passou a se concentrar sobre a mobilidade urbana de modo mais amplo, sem conferir a ênfase até então atribuída à questão tarifária. Coerentemente, mudou-se o nome de Frente de Lutas Contra o Aumento para Frente de Lutas Pelo Transporte Público.

Em 27 de setembro de 2013 ocorreram dois protestos simultâneos, organizados, respectivamente, por professores da rede municipal e pela FLTP. Em 3 de outubro de 2013 ocorreu um ato com número reduzido de aderentes que terminou, novamente, com ativistas sitiados pela Polícia Militar na Faculdade de Direito da UFG.

O ano de 2013 encerrou-se com a conquista, ao menos formal, da política de passe livre estudantil na região metropolitana de Goiânia. A medida, todavia, ainda dependeria de um acordo entre governo estadual e prefeituras municipais, para distribuição do impacto orçamentário entre os diferentes entes federativos. A legislação referente à política pública de isenção tarifária para estudantes só seria definitivamente sancionada em maio do ano seguinte.

Já em 2014, os atos públicos que se seguiram até o anúncio de um novo aumento tarifário reivindicaram, principalmente, o retorno de uma política pública denominada "Ganha-tempo", que permitia ao usuário do sistema de transporte a realização de três viagens de ônibus com uma passagem, durante um período de duas horas e trinta minutos. A política fora afastada por decisão judicial expedida em ação movida por empresas concessionárias do serviço de transporte. Outras pautas que mobilizaram os ativistas referiram-se a melhorias na qualidade do transporte e imediata implementação do projeto do passe livre estudantil, além da reversão de suas limitações e condicionalidades.

No dia 6 de fevereiro, um protesto pacífico foi encerrado pela Cavalaria e pela Tropa de Choque da Polícia Militar. Uma vez mais, os aderentes refugiaram-se na Universidade Federal de Goiás, de onde saíram após negociação entre advogados e a PM, que, novamente, cercava os manifestantes. Nos dias 13 e 26 de fevereiro e 8 de março de 2014, novos protestos organizados pela FLTP ocorreram.

Sob novo anúncio do aumento da tarifa, em 15 de abril a FLTP e outras organizações articularam um "dia de lutas". Seis protestos foram planejados, mas apenas dois ocorreram, além de uma paralisação de terminal, organizada espontaneamente por usuários do transporte. Em 9 de maio de 2014 ocorreu outro protesto, ao final do qual verificou-se a depredação de alguns ônibus por pessoas não identificadas. Em 21 de maio realizou-se mais um protesto, durante contexto em que os motoristas de ônibus preparavam a realização de uma greve. A tensão com os policiais e a presença sempre crescente de militares à paisana foram um atributo marcante desse período.

Ao longo de 2014, uma nova constelação de mobilizações somou-se aos protestos organizados pela FLTP. Revoltas espontâneas - sem qualquer direção política ou prévio planejamento - em terminais, ocorrentes sob o contexto de atrasos ou superlotações dos coletivos, tornaram-se frequentes na rotina de Goiânia e região metropolitana. Nessa situação, ônibus foram destruídos e terminais ficaram temporariamente fechados. Os 
problemas do transporte público e a inexistência de canais de diálogo entre município, estado e usuários de coletivos ganhavam nova dimensão e passavam a integrar de modo central a agenda pública da cidade, sob um ambiente de incontida e disseminada rebeldia civil. A proliferação das revoltas espontâneas implicava, como nunca, potenciais e efetivos prejuízos aos concessionários do serviço público de transporte coletivo urbano.

No dia 23 de maio de 2014, como já se expôs, deflagrou-se a operação policial "2,80". Três ativistas, com idades entre 18 e 19 anos, tiveram suas casas invadidas às 6 da manhã por homens vestidos de preto e encapuzados (um traje quase idêntico ao dos militantes que aderem à tática black-bloc). Os rapazes foram algemados (em contrariedade à Súmula Vinculante número 11/STF) e conduzidos a uma Delegacia. Ali, prestaram depoimentos e seguiram para um presídio. Dentre os indícios de crimes recolhidos em suas residências havia um livro publicado pela editora Boitempo, instrumentos musicais, cartazes e panfletos de lutas sociais ocorridas em outros espaços e tempos, como o "Maio de 1968" francês. Adicionalmente, foram apreendidos microcomputadores. Os jovens foram acusados de depredar ônibus, mas tudo o que havia no inquérito policial em seu desfavor era o depoimento de um militar reformado que exercia a função de "gestor de segurança e risco" das empresas de transporte. Dominium, como nos últimos dias do Império Romano, parecia condicionar as ações de Imperium.

Um preso político, o artista gráfico Heitor Vilella, de 19 anos, estudante de comunicação social da UFG, foi acusado de incitação ao crime por confeccionar panfletos e cartazes contra o aumento de tarifas de transporte. Ian Oliveira, também de 19 anos, foi acusado de participar de um protesto em que um ônibus teria sido incendiado na data de 9 de maio de 2014. O jovem, contudo, encontrava-se, na referida data, precisamente no Instituto de Ciência Política (Ipol), da Universidade de Brasília, apresentando um trabalho acadêmico no $2^{\circ}$ Simpósio Nacional Democracia e Desigualdades. Um terceiro detido, João Marcos, é um jovem secundarista que completou 18 anos em abril de 2014 e participa, como inúmeros colegas de sua escola, de algumas manifestações. Havia, ainda, um quarto estudante, matriculado na UFG, chamado Tiago, contra quem fora expedido mandado de prisão, que, todavia, não chegou a ser cumprido, uma vez que as autoridades policiais não o encontraram. Nos autos do inquérito policial, os ativistas eram descritos como "subversivos" - léxico estranho ao ordenamento jurídico brasileiro desde a redemocratização - e a FLTP era predicada como "organização criminosa".

Esse contexto gerou indignação junto à sociedade civil goianiense, especialmente em meio aos movimentos sociais e à intelectualidade. A OAB demandou explicações sobre as prisões e pleiteou respeito aos direitos fundamentais dos detidos. O reitor da UFG compareceu à Delegacia de Polícia e, dias após, reuniu-se com o presidente do Tribunal de Justiça ${ }^{17}$, solicitando que o caso fosse abordado conforme a legalidade e a

\footnotetext{
17 Um dos autores deste artigo participou da reunião. Estiveram presentes, ainda, o juiz auxiliar da presidência do Tribunal e um tenente-coronel da Polícia Militar.
} 
constitucionalidade. Uma ampla assembleia, na tarde do sábado, dia 25 de maio, reuniu mais de 300 pessoas no auditório da Faculdade de Educação da UFG. Ali, todo o espectro político de esquerda se viu coeso e unido contra os partidos no governo (PT, PMDB e PSDB), a Polícia Militar, a Polícia Civil, o Ministério Público e o Poder Judiciário. Um documento contra a criminalização dos movimentos sociais foi unanimemente aprovado por uma coletividade composta de intelectuais independentes, anarquistas, maoistas, trotskistas, stalinistas, teólogos da libertação, prestistas, autogestionários e toda uma amplíssima constelação de forças e de ideologias políticas. Em poucas horas, havia mais de 2 mil subscrições, advindas de todo o mundo ${ }^{18}$.

No dia 27 de maio, terça-feira, um massivo ato público promoveu, novamente, a unidade da esquerda política goianiense e tomou as ruas da cidade, em direção ao Tribunal de Justiça ${ }^{19}$. No dia 29 de maio, quinta-feira, durante a manhã, novo protesto ganhou o centro de Goiânia, agora com o apoio de professores municipais. Os manifestantes exigiam a imediata libertação dos detidos, que só ocorreria na noite de 29 de maio. Essas duas manifestações ocorreram sem conflitos entre os presentes - dentre os quais se incluíam diretores de unidades da UFG, membros da OAB e figuras públicas locais - e as forças policiais.

O caso ganhou ímpar visibilidade nos veículos de comunicação locais e o enquadramento oscilou de uma imagem negativa dos presos políticos, para a realização de perfis laudatórios, contando a trajetória acadêmica e os hábitos de vida dos jovens. A mudança de enquadramento midiático seguiu o curso das adesões aos protestos de rua e às manifestações de solidariedade nos espaços virtuais.

O episódio é especialmente relevante porquanto, de um modo pouco comum na história recente do país, uma prefeitura concedente do serviço de transporte, empresários do segmento, Polícia Militar, Polícia Civil, Ministério Público e Poder Judiciário agiram de maneira coordenada e eficiente para prender preventivamente ${ }^{20}$ militantes de um movimento social.

Após as prisões e a torrente de solidariedade e de protestos imediatamente

18 O conteúdo da nota pode ser acessado neste endereço: <http://passapalavra.info/2014/05/95539>. Último acesso: 22 jun. 2014.

${ }^{19} \mathrm{O}$ juiz auxiliar da presidência do Tribunal, acompanhado de um tenente-coronel da PM, recebeu uma comissão constituída por familiares dos presos e advogados. Na ocasião, foi entregue o documento público, já com mais de 2 mil assinaturas, em favor da libertação dos ativistas. Um dos autores deste artigo esteve presente à reunião.

20 Sob o aspecto processual-penal, a prisão preventiva só ocorre em situações excepcionalíssimas. Isso se dá porque, diferentemente da prisão temporária, por exemplo, ela não tem um prazo fixo de duração e pode perdurar indefinidamente, enquanto prosseguir a instrução criminal. O STF tem entendido que, em qualquer caso, essa forma de prisão cautelar não pode ultrapassar 81 dias, período, de todo modo, muito superior ao de outras modalidades de prisão anterior à condenação. No caso estudado, há uma particularidade que desperta a atenção: se os jovens fossem condenados com as maiores penas por todos os crimes investigados, não ficariam, ainda assim, presos em regime fechado. Em suma, durante a simples apuração de supostos crimes, eles já se encontravam em situação mais gravosa do que na hipótese de condenação nos mais rígidos termos. Esse quadro já foi classificado pelo STF, em reiteradas decisões, como abusivo. Um levantamento informal junto a ativistas, advogados e pesquisadores de movimentos sociais sugere que esse foi o primeiro caso de expedição de mandado de prisão preventiva contra militantes, desde os acontecimentos de junho de 2013. 
ocorrentes, a FLTP conseguiu se reunir em poucas ocasiões e, no final de 2014, já estava em inatividade. O receio de que novas ações coercitivas ocorressem e a preocupação com a vigilância estatal sobre os/as ativistas foram, sem dúvidas, como os pesquisadores puderam detectar em suas observações sobre reuniões e falas de militantes, fatores decisivos para a desarticulação do movimento. Não se trata, com efeito, de simples coincidência o fato de que os meses de abril e maio de 2014, marcos de novos e intensos protestos por mobilidade urbana em Goiânia, tenham sido sucedidos pelas detenções, e que estas - em que pese o lampejo das mobilizações em favor da liberdade aos detidos tenham desaguado em um quadro de crescente esmorecimento, cujo termo fora a inatividade da FLTP.

Em 4 de dezembro de 2014, quando a FLTP já havia se desarticulado, um pequeno grupo de jovens ligados ao movimento Tarifa Zero (outrora um dentre os inúmeros aderentes à FLTP) organizou um protesto diante da CMTC. Na ocasião, os/as ativistas se acorrentaram nas grades do órgão público e, fantasiados com máscaras de políticos e empresários do segmento de transporte coletivo, pleitearam políticas como a reintrodução do programa "Ganha-tempo". Foi, contudo, um evento aparentemente isolado, com pouca repercussão pública e nenhuma consequência direta.

A seção seguinte procura extrair conclusões da sucessão de episódios narrada neste artigo.

\section{Três "cisnes negros" identificados no estudo de caso}

A narrativa acima apresentada é relevante para que a ciência política brasileira descortine seu olhar para um conjunto de práticas que, usualmente, escapam ao seu radar $^{21}$. Trata-se de um caso em que, de um modo peculiarmente claro, pode-se identificar o significado do ativismo e dos protestos de rua no âmbito político. Estudos vinculados a objetos como comportamento eleitoral, jogos legislativos, coalizões de governos, espaços participativos ou trânsitos informais de fluxos comunicativos na esfera pública dificilmente explicariam, por exemplo, a produção da política pública de passe livre na região metropolitana de Goiânia. Ou seja, as lutas sociais travadas nas ruas por atores ainda neófitos nas disputas políticas nacionais e não adaptados aos ritos e procedimentos institucionais para solução de conflitos (espécies do gênero "transgressive contentious politics" (MacAdam, Tarrow e Tilly, 2004 ${ }^{22}$ ) possuem tanta relevância nos estritos limites da ciência política - que ainda as trata com menor apreço no Brasil -

\footnotetext{
21 Soma-se à apresentação acima mencionada (Tavares, 2015) um recente estudo repleto em dados empíricos sobre publicações do campo da ciência política no Brasil, a lastrear a tese de um itinerário histórico que o conduziu à prevalência de publicações orientadas pelo neoinstitucionalismo (Limongi, Almeida e Freitas, 2015).

22 Confira-se a íntegra da definição: "Transgressive contention consists of episodic, public, collective interaction among makers of claims and their objects when (a) at least one government is a claimant, an object of claims, or a party to the claims, (b) the claims would, if realized, affect the interests of at least on of the claimants, (c) at least some parties to the conflict are newly self-identified political actors, and/or (d) at least some parties employ innovative collective action" (MacAdam, Tarrow e Tilly, 2004, p. 7-8).
} 
como em áreas em que são mais detidamente estudadas, a exemplo da sociologia política e da antropologia ${ }^{23}$. O fato é que o estudo do confronto político, como constatam MacAdam, Tilly e Tarrow nas primeiras linhas do célebre Dynamics of contention, há muito ingressou no campo da ciência política, exorbitando o prévio estatuto de assunto específico da psicologia social ou da sociologia. No Brasil, contudo, movimento semelhante não teve lugar com perceptível alcance, ao menos até aqui (Tavares, 2015).

Ademais, o caso estudado indica que a compreensão das relações de poder no Brasil contemporâneo, mesmo no mais estrito sentido weberiano de liderança ou influência sobre a máquina estatal, não pode ser analiticamente decomposta como uma disputa agrupada segundo os diferentes partidos institucionalizados no país. Ao contrário, é possível identificar-se, além das fronteiras do campo político-institucional, pressões e demandas organizadas que põem em xeque aquilo que irmana os partidos no regime. Ciclos de protestos populares, como o do caso apresentado, costumam aclarar as solidariedades e cumplicidades, antes da competição, entre os jogadores do campo político (e.g., PT, PSDB, PMDB etc.) porque o seu próprio jogo se revela ameaçado. Nas palavras de Bourdieu:

Esta solidariedade de todos os iniciados, ligados entre si pela mesma adesão fundamental aos jogos e às coisas que estão em jogo, pelo mesmo respeito (obsequium) do próprio jogo e das leis não escritas que o definem, pelo mesmo investimento no jogo de que eles têm o monopólio e que precisam perpetuar para assegurar a rentabilidade dos seus investimentos, não se manifesta de modo tão claro como quando o jogo chega a ser ameaçado enquanto tal (Bourdieu, 2012, p. 173).

Por um lado, sabe-se que as práticas repressivas que têm lugar no calor de protestos contam, na maioria dos países ocidentais, com um "alto grau de discricionariedade" (Della Porta e Reiter, 1998) dos agentes policiais que estão em campo. Assim, não seria possível estabelecer uma relação causal, linear e geral entre a repressão aos protestos de junho e uma cumplicidade guardada por governantes que, mesmo em partidos diferentes, teriam agido em conjunto para coibir a política de confronto transgressiva exercida por novos atores que chegaram à cena pública em 2013.

Por outro lado, há o peculiar cenário brasileiro, em que o policiamento de lei e ordem é militar, sob pleno comando dos governos estaduais. Assim, de modo ainda mais rígido do que o ocorrente com as gendarmerias na França, as decisões estratégicas,

\footnotetext{
${ }^{23}$ Um indício dessa constatação é o fato de que autores como C. Tilly e S. Tarrow, cujas obras se dedicam, em grande parte, ao estudo do confronto político, constam como "integradores" e "líderes" do campo disciplinar da ciência política, conforme o levantamento de citações realizado por Robert E. Goodin (2011). Ainda assim, há quem pondere que, mesmo em âmbito global, a lacuna aqui atribuída ao campo disciplinar em sua variante brasileira também se apresente. Confira-se: "Given the crucial importance of social movements to democracy, it is curious how little attention is generally paid to social movements by political scientists, or in democracy studies with their emphasis on electoral politics and representational forms of political participation" (Fominaya, 2014a, p. 4).
} 
como desobstrução coerciva de terminais, impedimento de que protestos alcancem avenidas específicas ou emprego de dispositivos como balas de borracha, são, em qualquer caso, proferidas ou aquiescidas por autoridades políticas, eleitas. No Brasil, em 2013, as práticas repressivas aconteceram, reiteradamente, em localidades onde o alvo preferencial dos protestos (prefeitos/as, por exemplo, responsáveis por políticas tarifárias de transporte público) pertencia a um partido político rival da autoridade política que comanda a polícia militar ${ }^{24}$ (governador/a). Esse, aliás, foi o caso de Goiânia, que parece fortalecer a hipótese - a ser discutida em estudos ulteriores - de uma "solidariedade dos iniciados", nos termos acima transcritos.

Além desses elementos, o caso em apreço, como se antecipou na seção introdutória, permite a produção de três refutações ("cisnes negros") a conjecturas ("generalizações") comuns à ciência política brasileira em seu estágio atual. Adiante, aborda-se cada uma delas de modo mais detido.

Para além do pensar sudestecêntrico: a origem periférica dos protestos de 2013

No epicentro de Goiânia, exatamente entre as duas mais movimentadas avenidas da cidade, há uma ostensiva estátua do bandeirante Bartolomeu Bueno da Silva, o Anhanguera, devidamente paramentado com vestes de conquistador e um fuzil em suas mãos. Sem favores, é o mais conhecido e visto monumento público da capital. Trata-se de um "presente" doado em 1942 à cidade pelo Centro Acadêmico XI de Agosto, da Faculdade de Direito da Universidade de São Paulo (USP). De um modo sucinto, é suficiente dizer que Anhanguera foi um bandeirante paulista que veio buscar ouro em solo goiano. A empreitada fora financiada em grande parte por seu genro, João Leite da Silva Ortiz, o fundador do Curral Del Rey, atual Belo Horizonte. Em suma, flutua sobre o ponto mais central e movimentado de Goiânia a inequívoca imagem do colonizador egresso do Sudeste (região mais industrializada e politicamente influente), devidamente doada pela juventude da USP, a mais renomada universidade brasileira.

Sob essa lógica colonial, não é surpreendente que o pensamento científico gestado no Sudeste se dedique, mesmo quando saído das penas de autores marxistas ou críticos, a entender fenômenos como os protestos de 2013 a partir de São Paulo, onde tudo teria começado. O cientista político André Singer aborda, por exemplo, em artigo publicado na New Left Review e reproduzido em português na revista Novos Estudos, os protestos de 2013 conforme a seguinte ordenação:

Os acontecimentos se dividiram em três fases, as quais duraram cerca de uma semana cada uma. A ebulição foi iniciada por fração pequena, embora valorosa, da classe média, com mobilizações praticamente circunscritas à

\footnotetext{
${ }^{24}$ Sobre a relação entre controle centralizado-militar de forças policiais e governos políticos, indicando a responsabilidade destes pela tomada das decisões principais (argumento defendido aqui), mas reconhecendo-se os rumos específicos que a ação policial pode tomar em campo, confira-se Fillieule e Jobard, 1998.
} 
cidade de São Paulo nos dias 6, 10, 11 e 13 de junho.

(...)

Com o início da Copa das Confederações (16 de junho), São Paulo perde centralidade, com o protagonismo passando às praças onde haveria jogos (Brasília, Fortaleza, Salvador, Belo Horizonte e Rio de Janeiro) (Singer, 2013, p. 24-26) 25 .

Outro pensador vinculado ao campo crítico, Plínio de Arruda Sampaio Júnior, professor da Unicamp, declarou que "[o]s protestos começaram em São Paulo e generalizaram-se por todo o Brasil, em uma resposta reativa das massas aos desmandos e arbitrariedades dos governantes" (Sampaio Júnior, 2013).

Não é necessária significativa sofisticação metodológica ou escavação empírica para concluir que os protestos de 2013 seguiram de Natal a Porto Alegre, de Porto Alegre a Goiânia e de Goiânia a São Paulo, em um encadeamento no qual as manifestações de uma localidade influenciaram, via redes sociais (como Facebook) e páginas de ativistas (a exemplo do sítio Passa Palavra), umas às outras. Em seu endereço na web, por exemplo, o Movimento Passe Livre (MPL) de São Paulo reproduziu, em 23 de maio de 2013, uma narrativa extraída do Passa Palavra sobre os protestos de Goiânia, seguida de uma declaração de apoio por parte do movimento paulista.

O desconhecimento sobre a gênese geográfica dos protestos merece maior investigação sobre a sua possível natureza de afirmação da "identidade dominante" pela "negação total do outro" (Santos, 2006, p. 250). A hipótese se torna mais plausível em um país, como o Brasil, onde o peculiar processo histórico forjou "condições para ao colonialismo externo suceder o colonialismo interno, para ao poder colonial suceder a colonialidade do poder" (Santos, 2006, p. 248).

A apresentação estampada na seção precedente, "Dias de luta: narrativa e periodização dos protestos em favor do transporte público na cidade de Goiânia entre maio de 2013 e dezembro de 2014", permite, assim, um primeiro rendimento científico deste estudo de caso: a refutação fático-histórica das narrativas sudestecêntricas conferidas aos protestos de 2013 no Brasil. O fato é que as "jornadas de junho" não apenas tiveram início em maio, como influenciaram, a partir da periferia, o repertório de ações e a pauta política do centro. O único critério apto a autorizar a tese de que os eventos de 2013 começaram em São Paulo seria aquele segundo o qual um fato político só é relevante - ou seja, só encontra a luz da história e chega à superfície como "existente" - quando se manifesta em alguma das três principais capitais do Sudeste.

\footnotetext{
${ }^{25}$ Essa visão que tem o Sudeste como centro e eixo não é traço permanente na obra do autor. Em seu livro Os sentidos do lulismo, Singer apresenta uma cuidadosa introdução dedicada à "questão setentrional" brasileira. Ali, sob inspiração da "questão meridional" gramsciana, o autor procura indicar como a aliança entre a burguesia do Sudeste e as oligarquias agrárias do Nordeste conforma a lógica de dominação do subproletariado brasileiro. Sem discutir o mérito da tese de "realinhamento eleitoral" proposta por Singer para explicar o Brasil a partir do segundo mandato de Lula, deve-se reconhecer que o autor confere relevante e ativo papel ao Nordeste e à sua população empobrecida na gestação de novos padrões políticos e partidários no Brasil (cf. Singer, 2012).
} 
O que esse "cisne negro" propõe, antes de uma hipótese rival sobre um mítico "marco zero" cronológico dos protestos, é a necessidade de um redirecionamento nas pesquisas sobre movimentos sociais e confronto político no Brasil, de modo que levem em alta consideração as dinâmicas e complexas relações entre as diferentes localidades de um país continental. Antes de propor que os protestos começaram em junho ou em São Paulo, mas, igualmente, antes de encerrar o assunto com a alternativa "maio" ou "Porto Alegre", a ciência social tem a ganhar a partir da compreensão de elementos relacionais, como, por exemplo, os seguintes: i) como se deram as relações centroperiferia no interior das organizações de movimentos sociais de alcance interestadual em 2013?; ii) de que modo foram utilizadas as novas tecnologias de informação e como auxiliaram ou obstruíram o espraiamento dos protestos no Brasil em 2013?; iii) quais foram as demandas regularmente observadas em âmbito nacional? Pensar o ciclo de protestos de 2013 como nacionalmente dimensionado e perquirir as relações entre as localidades (algo, em termos brasileiros, análogo ao que a obra coletiva organizada por C. Fominaya e L. Cox (2013) efetivou em escala europeia) seria mais fecundo do que simplesmente adotar São Paulo como centro espraiador dos protestos brasileiros.

Outra conclusão que o estudo apresentado neste artigo possibilita diz respeito à refutação da tese de uma clara ou irremediável fragmentação das lutas políticas conduzidas nas ruas em junho de 2013. Ao menos em Goiânia, as coisas não se passaram assim, como a subseção seguinte procura desenvolver.

\section{A coesão como regra nos protestos de rua entre maio de 2013 e dezembro de 2014 na cidade de Goiânia}

Reconhecidos cientistas políticos nacionais predicaram os protestos de 2013 como cacofonicamente repletos de pautas ou bandeiras imprecisas, contraditórias. O maior expoente dessa leitura sobre os episódios foi Wanderley Guilherme dos Santos ${ }^{26}$. O autor escreveu inúmeros artigos de opinião que, em geral, seguiam o tom das palavras a seguir transcritas:

Não existem, contudo, vozes das ruas, apenas alaridos. Não foram as cartolinas pintadas que levaram as primeiras multidões às passeatas, elas surgiram algum tempo depois das marchas em busca de um porquê das

\footnotetext{
26 No mesmo sentido escreveu Fabiano Santos, sobre o perfil dos manifestantes: "Uma coalizão a congregar militantes do Movimento pelo Passe Livre (MPL); jovens e não tão jovens radicais de esquerda, filiados a partidos como PSOL e PSTU; ativistas de causas sociais as mais diversas (índios, GLS, negros etc.); segmentos das classes alta e média alta e da nova classe média; órfãos de alternativas partidárias consistentes à direita do espectro político; anarquistas e ativistas conectados a movimentos internacionais de protesto; além de neonazistas e fascistas assumidos, adeptos da violência e da intolerância como meios legítimos de manifestação e expressão de preferências e valores. Desprovidos de uma reivindicação específica, como nos episódios das "Diretas Já" ou do impeachment do presidente Fernando Collor, encontravam-se todos ligados numa mesma emoção: participar, protestar, se expressar, eventualmente de forma violenta, gritar palavras de ordem, portar cartazes e vestir máscaras; enfim, sentir a euforia de fazer parte de um movimento de massas de inédita proporção" (Santos, p. 17-18, 2013a).
} 
próprias marchas. A seco, melhoras genéricas da saúde pública ou da educação não estimulam o deslocamento de dezenas de milhares de manifestantes. Reforma política, então, nem em cartolina apareceu.

(...)

Participam hoje dos protestos, fora os incautos e ingênuos que sempre existem e lhes emprestam ar de legitimidade, grupos anômicos de jovens de algumas posses, grupos neonazistas e pré-fascistas, organizações niilistas nacionais e internacionais, além das gangues ordinárias de ladrões e assaltantes (Santos, 2013).

O caso aqui estudado permite a refutação da supracitada generalização como um misto de sudestecentrismo (aspectos peculiares ao Rio de Janeiro são elevados ao patamar de análise sobre os protestos em geral), com o congelamento de um momento peculiar e circunstanciado dos atos de 2013 e 2014. Como se viu no particular exemplo histórico goianiense, apenas em 20 de junho de 2013 ocorreu uma multiplicidade contraditória e desorientada de causas, atores e táticas. Em todas as outras ocasiões, com destaque para os atos pela libertação dos presos políticos no ano de 2014, a coesão, o foco e a unidade entre amplas e plurais forças políticas foram a tônica das marchas de rua. A partir de uma análise detida e cuidadosa de cada manifestação ocorrente em Goiânia, é razoável supor que fenômeno correlato possa ter ocorrido no Rio de Janeiro, onde as marchas multitudinárias da Avenida Rio Branco podem ter sido sucedidas por movimentos inclusivos, democráticos e focados quanto às demandas apresentadas, como o Ocupa Câmara, o Fora Cabral e a Greve dos Garis.

A tese da explosão anômica dos protestos, de qualquer modo, está por ser demonstrada por meio de estudos que produzam levantamentos acoplados a séries compostas de uma variedade de eventos - a exemplo deste artigo - sobre todos os protestos de rua ocorrentes, ao menos, nas capitais do Brasil. O que a pesquisa apresentada neste artigo fez em Goiânia deve ser replicado em escala nacional, antes de autorizar a pertinência científica das ideias acima transcritas.

Ademais, assinalar aos protestos um caráter niilista ou anômico pode comprometer o ímpar rendimento teórico que estudos focados sobre os momentos de baixa atividade dos movimentos sociais nas ruas, ou mesmo de informalidade da insatisfação, podem emprestar à compreensão dos processos societais em que estão inseridos, mais do que a gênese de eventos ou episódios específicos. Declarar o niilismo, a anomia ou a incontrolável espontaneidade compromete as devidas situação e localização dos protestos em movimentos, demandas, organizações e comunicações que, mesmo sob intensidade menor, os precedem e os influenciam em significativa medida ${ }^{27}$.

Outro frequente desdobramento do sudestecentrismo na abordagem dos protestos

\footnotetext{
${ }^{27}$ Um exemplo de estudo que procurou entender um ciclo de protestos para além da "explosão" "sem precedentes" e "espontânea" foi efetivado por Cristina Fominaya, a propósito do 15-M espanhol (Fominaya, 2014b).
} 
brasileiros de 2013 recai sobre a relação entre repressão policial e mobilização social. Em geral, remete-se ao caso de São Paulo, onde a percepção negativa da atuação da Polícia Militar em uma passeata impactou sobre a adesão multitudinária à mobilização subsequente. Não são estabelecidas, em geral, as devidas ressalvas e nuances atinentes à impossibilidade de generalização do mecanismo ou encadeamento fático-social ali ocorrente. Esse é o tema da próxima subseção.

Efeitos ambivalentes da repressão política sobre protestos e mobilizações: apontamentos a partir do caso goianiense

Os protestos ocorridos em Goiânia entre maio de 2013 e dezembro de 2014 foram, em sua quase totalidade, pacíficos. Os episódicos atos de depredação concentraram-se, quase sempre, em revoltas espontâneas, sem direção política. O movimento estudado esteve distante de se definir, quanto aos seus objetivos, como um grupo antirregime ou revolucionário, ainda que organizações com tais desígnios fossem uma fração do seu amplo e plural mosaico. As demandas orientavam-se prevalecentemente em favor do cumprimento de normas jurídicas já positivadas, tais como modicidade de tarifas (Lei 8987/95), eficiência do serviço público (Constituição, EC19), livre manifestação do pensamento (Constituição, art. 50) e gestão participativa da cidade (Lei 10.257/2001). Antes de reivindicarem novos direitos - o que fizeram em menor escala, ao pleitear o Passe Livre -, os ativistas se limitaram à moderada pauta do cumprimento da legislação por parte do Poder Público. Isso parece, todavia, ter sido suficiente para que eles não estivessem seguros em Goiânia e região.

Durante a atuação como advogado dos militantes presos, um dos autores deste artigo surpreendeu-se com o volume de telefonemas que recebia diariamente, oscilando entre 120 e 150 ligações. A quase totalidade das chamadas era proveniente de estudantes ou de lideranças de movimentos ou sindicatos, e tinha o constante conteúdo de uma indagação semelhante ao seguinte: "professor, você pode me dizer se eu sou citado em algum inquérito policial e se há alguma chance de ser o próximo preso?". Dezenas de pessoas deixaram a cidade às pressas no contexto da prisão dos estudantes. Até mesmo o coletivo de advogados, integrado por cinco pessoas, dentre as quais um membro do Conselho Federal da $O A B$, não podia exercer suas funções em regime de normalidade jurídico-institucional. Um tenente-coronel determinou que eles deveriam ser escoltados, no prédio do Poder Judiciário, por quatro policiais militares que Ihes faziam um apertado cerco em forma de círculo e acompanhavam os respectivos passos. Uma advogada teve sua moradia vigiada e precisou se mudar temporariamente.

Como detalhou a narrativa desenvolvida na terceira seção, "Dias de luta: narrativa e periodização dos protestos em favor do transporte público na cidade de Goiânia entre maio de 2013 e dezembro de 2014", o caráter pacífico dos protestos não impediu seu desfecho em repressão policial. A persecução penal voltada à apreensão de livros, panfletos e instrumentos musicais e à detenção de jovens entre 18 e 20 anos foi o 
corolário de um processo de cerceamento do movimento que já se revelava nítido nas manifestações de rua.

De outro lado, os canais de interlocução com as demandas dos ativistas estiveram, por todo o tempo, obstruídos. Estado e município jamais receberam os manifestantes, como se infere da narrativa exposta na seção antecedente. A cidade, ademais, é pouco pródiga em espaços abertos à participação social. Não há, por exemplo, uma política de orçamento participativo, hoje comum em grandes capitais. São pouco frequentes, igualmente, as práticas como consultas públicas ou audiências abertas à sociedade.

Opostamente, experimenta-se uma incomum militarização da cena político-estatal. Desde a administração escolar, seguindo-se pela relação com movimentos sociais, a Polícia Militar exerce em Goiás, e, particularmente, na capital Goiânia, um conjunto de funções sempre crescente e estranho ao rol de competências que a Constituição da República Ihe entrega ${ }^{28}$. O estado de Goiás saltou, de 2011 para 2014, da $17^{\text {a }}$ para a $7^{\text {a }}$ posição nacional em número de policiais militares por habitante (Goiás, 2014). Essa mudança foi, em grande medida, propiciada por uma figura específica dessa unidade federativa, atinente ao "Policial Militar Voluntário". Trata-se de um profissional fardado, armado, revestido de todas as prerrogativas policiais, mas alheio ao quadro de servidores concursados e estáveis do estado e à carreira da Polícia Militar.

O aumento do número de policiais não parece impactar claramente a criminalidade ou a delinquência na cidade. Um indício dessa hipótese é que o número de homicídios por 100 mil habitantes oscilou de 33,6 em 2011 para 43,26 em 2012 e, em contínuo acréscimo, 44,56 em $2013^{29}$ (cf. Melo, 2015). O combate à criminalidade é de tal modo ineficiente que o estado é alvo de um Incidente de Deslocamento de Competência provocado no STJ pela Procuradoria Geral da República, em função da inépcia de suas instituições (Polícia, Ministério Público e Judiciário) para apurar, processar e julgar contumazes e sistemáticos assassinatos de moradores de rua na região metropolitana de Goiânia.

O quadro acima delineado sugere pertinência ao insight foucaultiano sobre a relação entre vigilância policial e criminalidade. Para Foucault, "a prisão provoca, produz, fabrica delinquentes, delinquentes profissionais", arrematando que "o medo do crime, que é permanentemente atiçado pelo cinema, pela televisão e pela imprensa, é a condição para que o sistema de vigilância policial seja aceito" (Foucault, 2012, p. 107). Não há frustração ou contradição no aumento do aparato policial concomitante à escalada da criminalidade em Goiás. São partes de um mesmo fenômeno, já que este último quadro, se o teórico citado estiver correto, é o principal justificador daquele. Malograda na redução dos indicadores penais, a hipertrofia das forças policiais concorre para a edificação de um aparato de vigilância que se nutre e depende da delinquência

\footnotetext{
${ }^{28}$ Em declaração pública, o governador do estado chegou a expressar que a militarização de escolas seria um "remedinho" contra professores sindicalistas que o teriam vaiado em uma cerimônia (Pulcineli, 2015).

${ }^{29}$ Os números absolutos oscilaram de 479 em 2011 para 658 em 2014, experimentando crescimento em todos os anos (cf. Melo, 2015).
} 
comum. É dela que angaria a legitimidade da sua máquina. Trata-se, de novo com Foucault, de "efeitos que são retomados em diferentes usos, os quais são racionalizados, organizados em função de novos fins" (Foucault, 2012, p. 284). A irracionalidade institucional é, portanto, ajustada em perspectiva reversa, de modo que o efeito adverso (aumento de criminalidade) torna-se pretensão ambicionada, na condição de fator de legitimação do aparato - político - de controle e vigilância.

O caso estudado permite a formulação da hipótese, a ser mais detidamente testada em estudos ulteriores, de que um efeito do aumento do aparato policial que é retomado com uso diferente daquele para o qual fora concebido reside, de modo mais específico, na repressão à oposição política que se organiza às margens do espectro partidário com representação parlamentar. Em Goiânia, é seguro dizer que, em uma ação deliberada e municiada por fartos recursos, a articulação entre inteligência da polícia civil, polícia militar e delegacia especializada contribuiu, decisivamente, para a inatividade do principal movimento social em atuação na cidade, a FLTP, que congregava diversas organizações e associações sem assento nos Legislativos. A legitimidade de tão robusto aparato encontra-se em um suposto combate à delinquência, que não se efetiva e não pode se efetivar por meios policiais.

No caso em estudo, a chamada "Operação 2,80" foi o marco a partir do qual apreensões, detenções e ameaças de novas prisões em grandes meios de comunicação marcaram o ponto de virada que levou à inatividade da FLTP. Adicionalmente, os próprios dados científicos (documentos, gravações de entrevistas, questionários etc.) armazenados no computador apreendido jamais foram restituídos. Comprometeu-se, desse modo, não apenas o movimento, mas sua memória e compreensão acadêmica. Tal sucessão de episódios conduz o estudo de caso relatado neste artigo a um terceiro "cisne negro" atinente às ideias preponderantes nas abordagens científicas sobre os protestos brasileiros de 2013. Trata-se da relação entre repressão policial e massificação das manifestações. Moraes e Santos, por exemplo, apontam uma dimensão nacional para uma sucessão causal de alcance estritamente local. Confira-se:

Tudo começou com um ato de protesto político contra o aumento das passagens de ônibus em São Paulo, encabeçado pelo Movimento Passe Livre, mas, por conta da intensa violência policial que veio como resposta, uma onda de insatisfação se espalhou pelo país dando inicio à "primavera brasileira" (Moraes e Santos, 2013) ${ }^{30}$.

A subseção antecedente discutiu os problemas da ideia de que "tudo começou" com os protestos de São Paulo. O problema que aqui interessa debater atém-se ao prosseguimento do argumento, segundo o qual "por conta" da violência policial uma

\footnotetext{
30 Esse foi o tom de numerosos estudos e análises. Confira-se um segundo exemplo: "As manifestações que se alastraram pelas ruas do Brasil em junho de 2013, motivadas inicialmente pela ação truculenta da polícia nos protestos contrários ao aumento da passagem urbana em São Paulo" (Alzamora, Arce e Utsch, 2014, p. 39).
} 
"primavera brasileira" teria ocorrido. Não se enfrentam, aqui, os limites teóricos da ideia de "primavera brasileira", a associar sem maiores nuances e mediações os protestos brasileiros aos congêneres ocorrentes em 2011 e 2012 no Oriente Médio e no norte da África (para não se regredir à "Primavera dos Povos", na Europa de 1848, o que seria ainda mais problemático). Trata-se, apenas e especificamente, de sugerir-se, a partir do estudo de caso empreendido, que a violência policial desencadeou, no máximo, uma "primavera paulista". Em Goiânia, os protestos se iniciaram antes, prosseguiram até 2014 e, claramente, cessaram ou minguaram em decorrência da ação policial. A relação entre repressão e aumento dos protestos não permite, portanto, generalizações ou formulações que tentem explicar o que ocorreu em todo o Brasil. Ao contrário, o caso de Goiânia parece conceder razão a Charles Tilly. Ao concluir uma extensa obra coletiva dedicada a estudos teóricos e empíricos referentes à relação entre repressão e mobilização, o autor pede atenção à linha de raciocínio para a qual essa relação "aplica nomes a classes de episódios para os quais explicações coerentes são possíveis - mas não na forma de leis gerais nos níveis de episódios ou classes de episódios"31 (Tilly, 2004, p. 211). Mais do que propor que a repressão incendeia ou arrefece processos de mobilização, é o caso de se avançar os estudos para se identificar as dinâmicas de conflitos que explicam os processos e mecanismos nos quais diferentes episódios, mesmo com atributos comuns (luta por mobilidade em capitais brasileiras, por exemplo), possuem diferenças (relação entre repressão e mobilização).

A partir desse terceiro "cisne negro" oferecido pelo estudo de caso realizado, uma agenda de estudos voltados à compreensão da relação entre repressão e mobilização no Brasil pode ter lugar, de modo a entender melhor como, com quais oscilações e com qual intensidade se dá tal vínculo.

Por fim, propõe-se que a compreensão acadêmica do conflito político levado às ruas entre 2013 e 2014 no Brasil tende a ganhar em rigor e refinamento se considerar os três elementos aqui realçados e usualmente não vislumbrados pelos trabalhos que se debruçam sobre o tema: i) os protestos não começaram em São Paulo; ii) a multiplicidade ou contradição entre as demandas não foi uma constante nas manifestações; e iii) a repressão policial despertou, em diferentes momentos e localidades, tanto indignação propulsora de grandes atos públicos quanto inibição ou contenção de movimentos.

Francisco Mata Machado Tavares - professor adjunto de ciência política na Faculdade de Ciências Sociais da Universidade Federal de Goiás (UFG). Email: <franciscotavares@ufg.br>.

João Henrique Ribeiro Roriz - professor adjunto de relações internacionais na Faculdade de Ciências Sociais da Universidade Federal de Goiás (UFG). E-mail: <joao.roriz@gmail.com>.

Ian Caetano de Oliveira - mestrando em Ciência Política na Universidade Federal de Goiás (UFG). E-mail: <ian_gyn@hotmail.com

\footnotetext{
31 Tradução livre. No original: "apply names to classes of episodes for which coherent explanations are possible - but not in the form of general laws at the levels of episodes or classes of episodes".
} 


\section{Referências bibliográficas}

Alzamora, G. C.; ARCE, T.; UTSCH, R. S. Acontecimentos agenciados em rede: os eventos do Facebook no dispositivo protesto. In: SiLvA, R. H. A. (org.). Ruas e redes: dinâmicas dos protestos (BR). Belo Horizonte: Autêntica, 2014.

BORGES, F. "Goiânia é a 28 a colocada em ranking das cidades mais violentas do mundo". G1, 24/3/2014. Disponível em: <http://g1.globo.com/goias/noticia/2014/03/goiania-e-28-colocada-emranking-das-cidades-mais-violentas-do-mundo.html>. Acesso em: 17 jun. 2014.

Bourdieu, P. O poder simbólico. Trad. Fernando Tomaz. 16a ed. Rio de Janeiro: Bertrand Brasil, 2012.

BRINGEL, B. "Miopias, sentidos e tendências do levante brasileiro de 2013". Insight Inteligência, São Paulo, vol. 67, p. 43-51, out. 2013.

Brydon-Miller, M.; Greenwood, D.; Maguire, P. "Why action research?". Action Research, vol. 1, nº 1, p. 29-38, Londres, Sage, 2003.

DAHL, R. A. Poliarquia: participação e oposição. Trad. Celso Mauro Paciornik. São Paulo: Edusp, 2012.

DeLla PoRTA, D.; ReITER, H. Introduction: the policing of protests in western democracies. In: Della PORTA, D.; REITER, H. (eds.). Policing protest: the control of mass demonstrations in western democracies. Londres: Minessota University Press, p. 1-34, 1998.

DouZiNAS, C. "Athens uprising". European Urban and Regional Studies, vol. 20, n 1, p. 134-138, 2013.

FERES JÚNIOR, J. "Aprendendo com os erros dos outros: o que a história da ciência política americana tem para nos contar". Revista de Sociologia e Política, Curitiba, nº 15, p. 97-110, nov. 2000.

FillieUle, O.; JobARD, F. The policing of protest in France: toward a model for protest policing. In: Della PORTA, D.; ReITER, H. (eds.). Policing protest: the control of mass demonstrations in western democracies. Londres: Minessota University Press, p. 70-90, 1998.

FominAYA, C. F. Social movements \& globalization: how protests, occupations \& uprisings are changing the world. New York: Pallgrave McMillan, 2014a.

Debunking spontaneity: Spain 15-M's Indignados as autonomous movement. Social Movements Studies: Journal of Social, Cultural and Political Protest, Londres, vol. 4, n 2, p. 142$163,2014 \mathrm{~b}$.

FominAYA, C. F.; Cox, L. (eds.). Understanding European movements: new social movements, global justice struggles, anti-austerity protest. New York: Routledge, 2013.

FLYVBJERG, B. Making social science matter: why social inquiry fails and how it can succeed again. Cambridge: Cambrigde University Press, 2011.

Foucault, M. Segurança, penalidade e prisão. Coleção Ditos e Escritos, vol. VIII (seleção de Manoel Barros da Motta). Rio de Janeiro: Forense Universitária, 2012.

Goiás. Secretaria de Estado de Planejamento. "Goiás supera média nacional em policiais por habitantes", 2014. Disponível em: <http://www.casacivil.go.gov.br/post/ver/171082/goias-superamedia-nacional-em-policiais-por-habitantes>. Acesso em: 24 fev. 2015.

Goodin, R. E. The state of the discipline, the discipline of the State. In: Goodin, R. E. (ed). The Oxford Handbook of Political Science. Oxford e Nova York: Oxford University Press, p. 3-60, 2011. 
HABERMAS, J. The crises of the European Union: a response. Cambridge: Polity Press, 2012.

LIMONGI, F.; ALmeidA, M. H. T.; FReITAS, A. Da sociologia política ao (neo)institucionalismo: trinta anos que mudaram a ciência política no Brasil, 2015. Texto preparado para o livro: AVRITZER, L.; MiLANI, C. (orgs.). Ciência política no Brasil: história, métodos, conceitos (no prelo). Disponível em:

<https://www.academia.edu/15209689/DA_SOCIOLOGIA_POL\%C3\%8DTICA_AO_NEO_INSTITUCIO NALISMO_TRINTA_ANOS_QUE_MUDARAM_A_CI\%C3\%8ANCIA_POL\%C3\%8DTICA_NO_BRASIL>. Acesso em: 20 set. 2015.

MAC AdAM, D.; TARROW, S.; Tilly, C. Dynamics of contention. Londres: Cambridge University Press, 2004.

Maquiavel, N. Discursos sobre a primeira década de Tito Lívio. São Paulo: Martins Fontes, 2007.

MARX, K. "Marx to Ruge". Kreuznach, september, 1843. Disponível em:

<http://www.marxists.org/archive/marx/works/1843/letters/43_09.htm>. Acesso em: 11 jan.

2013.

Melo, R. "Número de assassinatos sobe $6 \%$ e o de mulheres, 150\%". O Popular, Goiânia, 2/1/2015. Disponível em: <http://www.opopular.com.br/editorias/cidades/n\%C3\%BAmero-de-assassinatossobe-6-e-o-de-mulheres-150-1.747846>. Acesso em: 20 fev. 2015.

MORAES, T. P. B.; SANTOS, R. M. "Os protestos no Brasil: um estudo sobre as pesquisas na web e o caso da Primavera Brasileira". Revista Internacional de Investigación en Ciencias Sociales, vol. 9, n², p. 193-206, dez. 2013.

OLIVEIRA, M. "15 das maiores cidades têm um veículo para cada dois habitantes". G1, 2/11/2009. Disponível em: <http://g1.globo.com/Noticias/Carros/0,,MUL1361733-9658,00-

DAS+MAIORES+CIDADES+TEM+UM+VEICULO+PARA+CADA+DOIS+HABITANTES.html>. Acesso em: 12 jun. 2014.

PULCINELI, F. "Marconi diz ser contra estabilidade do servidor público". O Popular, 26/11/2015. Disponível em: <http://www.opopular.com.br/editorias/blogs/fabiana-pulcineli/blog-da-fabianapulcineli-1.526/marconi-diz-ser-contra-estabilidade-do-servidor-p\%C3\%BAblico-1.995673>. Acesso em: 28 nov. 2015

SAMPAIO JÚNIOR, P. A. "Jornadas de junho e revolução brasileira". Interesse Nacional, São Paulo, vol. 6, n०23, p. 57-66, out.-dez. 2013.

SANTOS, B. S. A gramática do tempo: para uma nova cultura política. São Paulo: Cortez, 2006.

SANTOS, F. "Do protesto ao plebiscito: uma avaliação crítica da atual conjuntura brasileira". Novos Estudos, Cebrap, 96, jul. 2013a.

p. 33-38, out. 2013 b.

SANTOS, W. G. "Anomia niilista". Valor Econômico, 2013a. Disponível em:

<http://www.valor.com.br/cultura/3211228/anomia-niilista>. Acesso em: 19 jun. 2014.

SERodio, G. "Brasil é 40 país mais desigual da América Latina e Caribe, diz ONU". Valor Econômico, 21/8/2012. Disponível em: <www.valor.com.br>. Acesso em: 10 jun. 2013.

Silveira, S. A; Pimentel, T. "Cartografia de espaços híbridos: as manifestações de junho de 2013". (2013). Disponível em: <http://interagentes.net/?p=62>. Acesso em: 20 jun. 2014.

SINGER, A. Os sentidos do lulismo: reforma gradual e pacto conservador. São Paulo: Cia. das Letras, 2012. 
Singer, A. "Brasil, junho de 2013: classes e ideologias cruzadas". Novos Estudos, Cebrap, n 97, p. 23-40, nov. 2013.

TARRoW, S. O poder em movimento: movimentos sociais e confronto político. Trad. Ana Maria Sallum. Petrópolis: Vozes, 2009.

TAVARES, F. M. M. "As ruas e o fórum: a ciência política brasileira diante do ativismo e da participação social como formas de inclusão das vozes subalternas". Belo Horizonte: UFMG, 10 abr. 2015. Palestra ministrada no evento Postdoctoral Talks.

TILLY, C. Repression, mobilization and explanation. In: DAVENPORT C., et al. (eds.). Repression and mobilization. Minneapolis: University of Minesota Press, 2004.

\section{Resumo}

As jornadas de maio em Goiânia: para além de uma visão sudestecêntrica do junho brasileiro em 2013

O ano de 2013 apresentou, no Brasil, formas de contestação social que oferecem instigantes problemas à ciência política. Este artigo se situa nesse contexto para se dedicar à compreensão, mediante um estudo de caso, da Frente de Luta do Transporte Público (FLTP) na cidade de Goiânia. A indagação condutora da pesquisa é a seguinte: o que se pode inferir, a partir do caso da FLTP, sobre as mais comuns generalizações atinentes ao local dos acontecimentos, às demandas expressadas e à relação entre ativismo e repressão nos protestos que tiveram lugar no Brasil em 2013? Tal ampla questão é articulada em três eixos, nomeadamente: a relação entre o caso estudado e as tensões de ordem colonial que contrapõem o centro brasileiro, situado no Sudeste, às localidades periféricas, como o Centro-Oeste (i); a relação entre a FLTP e os outros movimentos ou partidos, em especial quanto à coesão ou ao foco das demandas pleiteadas (ii); e a relação da FLTP com o aparato coercitivo e penal-persecutório do Estado (iii). O artigo encerra um estudo de caso baseado na metodologia da pesquisa-ação. O seu principal resultado é a refutação de três generalizações comuns sobre os protestos brasileiros de 2013, atinentes ao local onde se iniciaram, às demandas apresentadas e à relação entre as manifestações e a repressão policial.

Palavras-chave: contentious politics; criminalização de movimentos sociais; metodologia da pesquisa-ação; jornadas de junho

\section{Abstract}

May journeys in Goiânia: beyond a "southeasterncentric" vision of Brazilian June in 2013

Brazil has faced in 2013 some forms of social contention that offer instigating problems to political science. The article departs from this context to comprehend by the means of a case study the Front of Struggles for the Public Transportation (FLTP) in the city of Goiania. The question that leads the research is the following: what could be concluded, from the case of FLTP, about the most common generalizations concerned to the place of the events, the protesters grievances, and the links between activism and repression during the protests that took place in Brazil in 2013? Such wide question is approached from three perspectives, namely: the relation between the case and the colonial tensions that confront Brazilian political center, placed in Southeast, to the peripheral regions, such as the Central West (i); the relation between the FLTP and political parties or other social movements, specially under the criterion of the cohesion or focus of the grievances (ii); and the relation between FLTP and the state persecutory apparatuses. The article comprises a case-study based on the methodology of action-research. Its main result is the refutation of three common generalizations about Brazilian protests in 2013, related to the place where the protests began, the claims presented by the adherents and the relation between police repression and the demonstrations. 
Keywords: contentious politics; social movements' criminalization; action-research metodology; June journeys

\section{Resumen}

Las jornadas de mayo en Goiânia: más allá de una visión sudeste-céntrica del junio brasileño en 2013

El año de 2013 se presentaron en Brasil formas de contestación social que representan problemas intrigantes para la ciencia política. El artículo se ubica en ese contexto para su entendimiento, mediante un estudio de caso, el Frente de Lucha del Transporte Público (FLTP) en la ciudad de Goiânia. La pregunta conductora de la investigación es la siguiente: ¿qué se puede inferir, a partir del caso de la FLTP, sobre las generalizaciones más comunes referentes al lugar de los hechos, a las demandas expresadas y a la relación entre activismo y represión en las protestas que ocurrieron en Brasil en 2013? Tan amplia cuestión es articulada en tres ejes, denominándolos como: la relación entre el caso estudiado y las tensiones de orden colonial que contraponen el centro brasileño, ubicado en el Sudeste, a las localidades periféricas, como el Centro-Oeste (i); la relación entre la FLTP y otros movimientos o partidos, en especial cuanto a la cohesión o foco de las demandas expresadas (ii); y la relación de la FLTP con el aparato coercitivo y penal persecutorio del Estado (iii). El artículo presenta un estudio de caso basado en la metodología de investigación-acción. Su principal resultado es la refutación de tres generalizaciones comunes sobre las protestas brasileñas de 2013, relativas al lugar donde se iniciaron, a las demandas presentadas y a la relación entre las manifestaciones y la represión policial.

Palabras clave: contentious politics; criminalización de movimientos sociales; metodología de investigación-acción; jornadas de junio

\section{Résumé \\ Les journées de mai à Goiânia: au-delà d'une vision Sudeste-centrique du Brésil sur les évènements de juin 2013}

Le Brésil, en 2013, a été le théâtre de formes de protestation sociale qui ont fourni d'intrigants problèmes aux sciences politiques. C'est dans ce contexte que se situe l'article, afin de se consacrer à la compréhension, à travers une étude de cas, du Front de lutte du transport public (FLTP) dans la ville de Goiânia. La question qui oriente cette recherche est la suivante: que peut-on déduire, à partir de l'affaire du FLTP, des généralisations les plus courantes relatives à l'emplacement des événements, aux demandes exprimées et à la relation entre l'activisme et la répression dans les manifestations qui ont eu lieu au Brésil en 2013? Cette vaste question s'articule autour de trois axes, à savoir la relation entre le cas étudié et les tensions d'ordre colonial qui confrontent le centre du Brésil, situé dans le Sud-Est, aux localités périphériques telles que le Centre-ouest (i); la relation entre le FLTP et d'autres mouvements ou partis, en particulier en ce qui concerne la cohésion et I'orientation des demandes requises (ii); et la relation entre le FLTP et l'appareil de l'état, coercitif et de persécution pénale (iii). Cet article conclut une étude de cas fondée sur la méthodologie de recherche-action. Son principal résultat est la réfutation de trois généralisations communes sur les manifestations brésiliennes en 2013, concernant le lieu où elles ont débuté, les demandes présentées et la relation entre les manifestations et la répression policière.

Mots-clefs: contentious politics; criminalisation des mouvements sociaux; méthodologie de la recherche-action; journées de juin 